Volume 9. Nomor 2. Januari 2014
Pandecta
http:/journal.unnes.ac.id/nju/index.php/pandecta

\title{
Perubahan Fungsi dan Struktur Bangunan Cagar Budaya Ditinjau dari Perspektif Undang-Undang Cagar Budaya
}

\author{
Sriayu Aritha Panggabean $\bowtie$
}

Mahasiswa Magister Hukum, Universitas Sumatera Utara, Indonesia

\begin{tabular}{l} 
Info Artikel \\
\hline Sejarah Artikel: \\
Diterima Oktober 2014 \\
Disetujui November 2014 \\
Dipublikasikan Desember 2014 \\
\hline Keywords: \\
Bangunan; \\
Cagar Budaya; \\
Perubahan; \\
Fungsi; \\
Struktur \\
\hline
\end{tabular}

\begin{abstract}
Abstrak
Penelitian ini bertujuan untuk menganalisis perubahan fungsi dan struktur Bangunan Cagar Budaya dilihat dari prspektif Undang-Undang Cagar Budaya. Selain itu, akan dianalisis mengenai proses perizinan pembanguan Semarang Contemporary Art Gallery yang dialihfungsikan. Penelitian ini menggunakan metode penelitian yuridis sosiologis dengan pendekatan kualitatif. Hasil penelitian ini menunjukkan bahwa tindakan Pemerintah Kota Semarang terhadap perubahan fungsi dan struktur bangunan Cagar Budaya sudah sesuai dengan Undang-Undang No. 11 Tahun 2010 Tentang Cagar Budaya yaitu sebagai tindakan revitalisasi bangunan tetapi dengan tidak merubah bentuk asli luar dari bangunan Cagar Budaya tersebut. Sementara itu, proses perijinan dalam pembangunan Contemporary Art Gallery dilakukan dengan mendapakan kajian dari Badan Pengelola Kawasan Kota Lama (BPK2L). Setelah itu, Dinas Tata Kota dan Perumahan Semarang akan berunding dengan Badan Pelestarian Cagar Budaya kota Semarang dan Lembaga Swadaya Masyarakat untuk mengeluarkan keterangan rencana kota serta ljin Mendirikan Bangunan yang dikeluarkan oleh Badan Pelayanan Perijinan Terpadu (BPPT). Ketika bangunan akan difungsikan maka BPPT akan mengeluarkan H.O (ljin Gangguan) dan SIUP (Surat Izin Usaha Perdagangan).
\end{abstract}

\begin{abstract}
This study aims to analyze changes in the function and structure of Heritage Buildings seen from prspectif Heritage Act. Moreover, it will be analyzed on the Development of the licensing process Semarang Contemporary Art Gallery are converted. This study uses socio-juridical research with qualitative approach. The results of this study indicate that Semarang government action to change the function and structure of the heritage buildings are in accordance with Act No. 11 Year 2010 on Heritage is a revitalization of the building but the action does not change the original shape of the building outside the Cultural Heritage. Meanwhile, in the construction permitting process conducted by the Contemporary Art Gallery assigned the study of the Old City Area Management Board (BPK2L). After that, the Department of Urban Planning and Housing Semarang will negotiate with the Heritage Preservation Board Semarang and NGOs to issue a City planning and building permit issued by the Integrated Licensing Service Agency (BPPT). When building will function then BPPT will issue HO (Disturbance Permit) and License (Trading License).
\end{abstract}

\begin{tabular}{lr}
\hline$\triangle$ Alamat korespondensi: & C 2014 Universitas Negeri Semarang \\
Magister Hukum, Universitas Sumatera Utara, Indonesia \\
e-mail: sriayu_panggabean@yahoo.com
\end{tabular}




\section{Pendahuluan}

Cagar Budaya sebagai warisan budaya bersifat kebendaan berupa Benda Cagar Budaya, Bangunan Cagar Budaya, Struktur Cagar Budaya, Situs Cagar Budaya, dan Kawasan Cagar Budaya di darat dan/atau di air yang perlu dilestarikan keberadaanya karena memiliki nilai penting bagi sejarah, ilmu pengetahuan, pendidikan, agama, dan/atau kebudayaan melalui proses penetapan. Hal tersebut berdasarkan Pasal 1 ayat (1) UU No. 11 Tahun 2010 tentang Cagar Budaya. Dalam hal ini, Cagar Budaya merupakan warisan kebudayaan materil yaitu perwujudan budaya sebagai hasil cipta karya manusia yang dapat digunakan oleh masyarakat untuk memenuhi kebutuhan serta melangsungkan hidupnya dan untuk hidup dengan baik. Adapun kebutuhan-kebutuhan tersebut adalah kebutuhan hidup mendasar, sosial dan psikologis (Waridah, 2004 : 150-152).

Suatu kota dapat dilihat dari hubungan "diorama kota" dengan sejarah masa lalunya seperti halnya yang diungkapkan oleh Kevin Lynch dalam bukunya yang berjudul Good City Form. Dengan kata lain, kota sebagai suatu "diorama" yang terpampang dalam museum sejarah dan di dalamnya terdapat rentetan peristiwa yang merefleksikan kesankesan tertentu seperti halnya kota Lama Semarang yang merupakan bagian dari sejarah Kota Semarang yang mempunyai citra visual fisik yang menyajikan kemegahan arsitektur Eropa di masa lalu.

Kawasan kota Lama Semarang merupakan satuan area yang mempunyai ciri khusus dan bentuknya menyerupai sebuah kota tersendiri. Batas kawasan kota Lama ialah kali Semarang di sebelah barat, Jl. Stasiun Tawang di sebelah utara, Jl. Ronggowarsito di sebelah timur, dan JI. Agus Salim di sebelah selatan. Sebelum tahun 1824 kota Lama dilingkungi bentek yang berbentuk segilima yang dinamai benteng Vijhoek. Untuk mempercepat jalur perhubungan antar ketiga pintu gerbang di benteng itu maka dibuat jalanjalan perhubungan, dengan jalan utamanya dinamai Heeren Straat yang saat ini bernama Jl. Let Jen Soeprapto. Salah satu lokasi pintu benteng yang ada sampai saat ini adalah
Jembatan Berok yang disebut De Zuider Por. Karena lokasi kota Lama yang strategis, dapat dengan mudah dicapai dari berbagai jurusan, terutama Jakarta - Surabaya. Selain itu, dalam lingkup kota, ketercapaiannya dari pusat-pusat lain juga sangat tinggi, yaitu pusat pemerintahan Kodya di Jl. Pemuda, pusat perdagangan Johar dan Jl. M.T. Haryono, dan pelabuhan Tanjung Mas.

Struktur kota Lama Semarang sebagai satuan area unik. Pola kawasan ini merupakan gabungan antara kota barat (Belanda) dengan lokal. Pada dasarnya pola yang terbentuk menjadi konsentrik dengan mode yang menjadi pusat kegiatan dan arus pergerakan. Sehingga kota Lama Semarang mendapat julukan "Little Netherland". Kawasan Kota Lama Semarang ini merupakan saksi bisu sejarah Indonesia masa kolonial Belanda lebih dari 2 (dua) abad, dan lokasinya berdampingan dengan kawasan ekonomi. Di tempat ini ada sekitar 50 bangunan kuno yang masih berdiri dengan kokoh dan mempunyai sejarah Kolonialisme di Semarang. Secara umum karakter bangunan di wilayah ini mengikuti bangunan-bangunan di benua Eropa sekitar tahun 1700-an. Hal ini bisa dilihat dari detail bangunan yang khas dan ornamen-ornamen yang identik dengan gaya Eropa. Seperti ukuran pintu dan jendela yang luar biasa besar, penggunaan kaca-kaca berwarna, bentuk atap yang unik, sampai adanya ruang bawah tanah. Hal tersebut menjadikan kota lama Semarang ditetapkan sebagai kawasan Cagar Budaya sesuai Undang-Undang No. 11 Tahun 2010 tentang Cagar Budaya.

Ditetapkannya kawasan kota Lama Semarang sebagai kawasan Cagar Budaya merupakan salah satu aset Kota Semarang yang mempunyai nilai penting sejarah dengan banyaknya bangunan kuno yang dinilai sangat berpotensi untuk dikembangkan di bidang kebudayaan ekonomi serta wilayah konservasi. Tetapi sampai saat ini. Sebagian bangunan di Kota lama berdiri sejak abad ke-18 M. Kebanyakan bangunan telah lapuk dimakan usia.

Pada pertengahan Januari dan April 2011 silam, sebanyak 2 (dua) bangunan Cagar Budaya roboh di kawasan Kota Lama, di Jalan Kepodang, Semarang. Sehingga total 
terdapat 3 (tiga) bangunan yang roboh di jalan kepodang dan 2 (dua) bangunan di Jalan merak. Satu-persatu bangunan cagar budaya di Kota Semarang bertumbangan disebabkan tidak dirawat oleh Pemerintah Kota Semarang. Seperti pada bangunan tua di Jalan Gelatik, Kelurahan Purwodinatan, Semarang Tengah yang ambruk pada tanggal 13 Januari 2013 (Kompas, Edisi 13/1/2013). Hal ini disebabkan oleh faktor usia bangunan dan faktor alam seperti : bencana banjir, rob dan intrusi air laut serta cuaca ekstrim (fenomena cuaca yang mempunyai potensi menimbulkan bencana).

Selain itu penanganan dari Pemerintah Kota Semarang yang dianggap lambat oleh masyarakat dan kesadaran dari masyarakat sendiri di sekitar kawasan Kota Lama Semarang yang masih minim serta kurang tegasnya hukum yang mengatur tentang Cagar Budaya di Kota Semarang sehingga menyebabkan satu-persatu bangunan Cagar Budaya di Kota Semarang menjadi tidak terawat dan tidak terurus dengan baik.

Sejumlah bangunan kuno di kawasan Kota Lama memang memprihatinkan. Hal ini menuntut perhatian semua pihak, terutama Pemerintah Kota Semarang. Sesuai dengan Pasal 19 Undang-Undang No. 11 Tahun 2010 tentang Cagar Budaya dinyatakan bahwa bangunan Cagar Budaya yang terbengkelai dan lalai tidak dipelihara, maka pemerintah bisa mengambil alih bangunan tersebut.

Dalam ketentuan Pasal 19 disebutkan bahwa setiap orang yang memiliki dan/atau menguasai Cagar Budaya paling lama 30 (tiga puluh) hari sejak diketahuinya Cagar Budaya yang dimiliki dan/atau dikuasainya rusak, hilang, atau musnah wajib melaporkannya kepada instansi yang berwenang di bidang Kebudayaan, Kepolisian Negara Republik Indonesia, dan/atau instansi terkait. Setiap orang yang tidak melapor rusaknya Cagar Budaya yang dimiliki dan/atau dikuasainya kepada instansi yang berwenang di bidang Kebudayaan, Kepolisian Negara Republik Indonesia, dan/atau instansi terkait paling lama 30 (tiga puluh) hari sejak diketahuinya Cagar Budaya yang dimiliki dan/atau dikuasainya tersebut rusak dapat diambil alih pengelolaannya oleh Pemerintah dan/atau Pemerin- tah Daerah. Hal ini selaras dengan kebijakan pemerintah daerah dalam konteks pengelolaan Public goods dan Public regulation yang sesuai dengan kebutuhan masyarakat (Kaloh, 2007 : 169).

Berdasarkan ketentuan Pasal 19 UU No. 11 Tahun 2010 tentang Cagar Budaya di atas menurut Penulis maka selain Pemerintah Kota Semarang, masyarakat juga memiliki kewajiban merawat bangunan Cagar Budaya. Akan tetapi, peraturan di atas masih bersifat umum karena tidak menyebutkan secara spesifik Cagar Budaya yang harus dilaporkan. Oleh sebab itu, Pemerintah Kota Semarang harus membentuk Peraturan Daerah Kota Semarang tentang Cagar Budaya. Hal yang sama juga diatur di dalam ketentuan Pasal 22 ayat (1) dan (2) Peraturan Daerah Provinsi Jawa Tengah No. 10 Tahun 2013 Tentang Pelestarian dan Pengelolaan Cagar Budaya Provinsi Jawa Tengah. Hal ini selaras dengan ketentuan Pasal 22 yang menyatakan bahwa setiap orang wajib memelihara Cagar Budaya yang dimiliki dan/atau dikuasainya. Cagar Budaya yang ditelantarkan oleh pemilik dan/ atau yang menguasainya dapat dikuasai oleh Pemerintah Daerah.

Berdasarkan hasil inventarisasi kepemilikan bangunan di kota lama, yang dilakukan DTKP (Dinas Tata Kota Perumahan) Kota semarang, saat ini baru sepertiga dari jumlah total yang diketahui pemiliknya. Bangunan kota lama tercatat berjumlah 105 bangunan. Sudah semestinya pemerintah memberi perhatian lebih pada bangunan-bangunan tua yang masih berdiri, meski secara struktur bangunan yang didirikan pada masa kolonial bisa bertahan lebih dari seratus tahun, bisa saja usianya lebih pendek karena kurang perawatan. Hal ini tentu berkaitan dengan kurang baiknya management dan maintenance. Sebagaimana dijelaskan dalam Pasal 11 ayat (3) Peraturan Daerah Provinsi Jawa Tengah No. 10 Tahun 2013 Tentang Pelestarian dan Pengelolaan Cagar Budaya dinyatakan secara tegas bahwa Pemerintah Daerah, atau setiap orang yang melakukan Penyelamatan wajib menjaga dan merawat Cagar Budaya dari pencurian, pelapukan, atau kerusakan.

Berdasarkan ketentuan tersebut, Penulis berasumsi bahwa apabila Pemerintah 
lalai dalam menjalankan kewajibannya dalam menjaga dan merawat Cagar Budaya maka seharusnya dapat dikenakan sanksi administratif dan pidana. Akan tetapi, sanksi tersebut belum dijelaskan dalam Peraturan Daerah Provinsi Jawa Tengah No. 10 Tahun 2013 tentang Pelestarian dan Pengelolaan Cagar Budaya Provinsi Jawa Tengah. Maka sudah menjadi keharusan untuk Pemerintah mengeluarkan Peraturan Kota Semarang tentang Cagar Budaya.

Sesuai dengan perubahan zaman, bangunan-bangunan tua di kota lama turut yang sudah ditetapkan menjadi bangunan Cagar Budaya turut berubah juga, baik dari segi fungsinya dan strukturnya. Sebagai contohnya adalah Gedung Keuangan Negara Semarang yang dulunya gedung Het Groote Huis (balai kota) yang menggantikan Staadhuist di Brajangan dimana bentuk keseluruhannya seperti balok persegi panjang maka gedung tersebut dinamakan Gedung Papak. Selain sebagai balaikota, gedung Papak tersebut juga difungsikan sebagai Kantor Polisi dan Kantor Karesidenan, Kantor Pos dan keuangan dan Ruang sidang Raad Van Justice (Pengadilan Untuk Rakyat Eropa). Pada tanggal 30 November 1954 Gedung Papak ini terbakar. Kemudian dibangun gedung dengan bentuk seperti sekarang ini. Fungsinya menjadi Gedung Keuangan Negara.

Dari segi struktur, terdapat beberapa bangunan-bangunan yang sudah mulai kehilangan struktur utamanya. Hal ini terlihat dari beberapa struktur bangunan yang sudah rusak termakan zaman dan tidak terawat, seperti dinding rusak, pintu dan jendela yang sudah mulai rapuh dan lain-lain. Sehingga perlu dukungan dari masyarakat maupun pemerintah untuk turut menjaga, melestarikan, serta mengembangkan Cagar Budaya berdasarkan ketentuan Pasal 11 ayat (3) Peraturan Daerah Provinsi Jawa Tengah No. 10 Tahun 2013 Tentang Pelestarian dan Pengelolaan Cagar Budaya. Selain itu negara bertanggung jawab dalam pengaturan pelindungan, pengembangan, dan pemanfaatan Cagar Budaya untuk melestarikan Cagar Budaya tersebut.

Cagar Budaya yang berupa benda, bangunan, struktur, situs, dan kawasan perlu dikelola oleh pemerintah dan pemerintah daerah dengan meningkatkan peran serta masyarakat untuk melindungi, mengembangkan, dan memanfaatkan cagar budaya tersebut. Dengan adanya perubahan paradigma pelestarian Cagar Budaya, maka diperlukan keseimbangan aspek ideologis, akademis, ekologis, dan ekonomis guna meningkatkan kesejahteraan rakyat.

Penelitian ini bertujuan untuk menganalisis perubahan fungsi dan struktur bangunan Cagar Budaya berdasarkan UU No. 11 Tahun 2010 tentang Cagar Budaya. Selanjutnya akan dianalisis mengenai proses perizinan Pemilik Bangunan Semarang Contemporary Art Gallery yang menjadikan bangunan cagar budaya berubah fungsi menjadi bangunan galeri seni kontemporer kepada Pemerintah Kota Semarang.

\section{Metode Penelitian}

Dalam penelitian ini menggunakan penelitian yuridis-sosiologis, yaitu penelitian hukum yang mempergunakan data primer (Soemitro, 1988 : 10). Untuk mendapatkan data primer diperoleh dari wawancara atau interview. Dalam hal ini, penulis melakukan wawancara dengan Pihak Dinas Tata Kota dan Perumahan Semarang, Pihak BAPPEDA, Akademisi, Pemilik Bangunan Semarang Contemporary Art Gallery dan masyarakat sebagai responden.

\section{Hasil Penelitian dan Pembahasan}

\section{a. Perubahan Fungsi dan Struktur Ban- gunan Cagar Budaya di Kota Semarang}

Semakin majunya pembangunan kota, menuntut masyarakat untuk memenuhi kebutuhan hidupnya sehingga membuat pemilik bangunan Cagar Budaya memanfaatkan bangunannya untuk kegiatan ekonomi. Semakin lama semakin banyak bangunan kuno yang berubah fungsinya. Salah satunya bangunan Semarang Contemporary Art Gallery yang terletak di Jl. Taman Sri Gunting No. 5-6 Semarang. Bangunan tersebut dulunya merupakan bangunan milik Belanda yang digunakan sebagai perusahaan yang berdagang berbagai macam barang keperlu- 
an rumah tangga dan keperluan kantor. Kini bangunan tersebut dialihfungsikan menjadi bangunan Galeri Semarang dengan pemilik barunya yang bernama Chris Darmawan. Bila hal tersebut dikaitkan dengan kegiatan perlindungan maupun pelestarian bangunan Cagar Budaya, pemanfaatan bangunan lama untuk mengakomodasi kegiatan baru yang relevan melalui alih fungsi dapat dipahami sebagai upaya interpretasi baru terhadap warisan budaya.

Alih fungsi merupakan pengalihan penggunaan bangunan dengan perubahanperubahan yang diperlukan. Proses ini adalah salah satu cara yang dapat dibenarkan dalam pelestarian bangunan bersejarah. Pengalihfungsian bangunan Cagar Budaya dilakukan dengan adanya perubahan-perubahan bentuk atau struktur bangunan baik secara keseluruhan maupun sebagian tanpa mempertimbangkan alasan pelaksanaan tekhnisnya maka bangunan Cagar Budaya tersebut dapat terancam hilang atau berubah bentuk baik sebagian maupun keseluruhan. Hal ini harus diperhatikan oleh Pemerintah Kota Semarang ketika melakukan perubahan fungsi dan struktur suatu bangunan Cagar Budaya selain melihat dari sisi fungsional-ekonomis juga dari sisi historis-filosofis bangunan tersebut.

Berdasarkan hasil wawancara penulis dengan pihak Dinas Tata Kota dan Perumahan Semarang bahwa alasan Pemerintah melakukan perubahan fungsi dan sktruktur bangunan Cagar Budaya adalah untuk merevitalisasi bangunan tersebut yaitu suatu kegiatan pengembangan yang ditujukan untuk menumbuhkan kembali nilai-nilai penting Cagar Budaya dengan penyesuaian fungsi ruang baru yang tidak bertentangan dengan prinsip pelestarian dan nilai budaya masyarakat. Sebagai salah satu tindakan pelestarian yang dilakukan oleh Pemerintah terhadap bangunan Cagar Budaya kota Semarang dengan cara menghidupkan kembali kawasan kota Lama Semarang yang mempunyai nilai falsafah dari segi pendidikan, sejarah maupun nilainilai penting yang terkandung di dalamnya. Bangunan Cagar Budaya yang memiliki citra tersendiri yang cukup memberi keuntungan brand image kepada pemilik usaha yang ber- sangkutan. Disadari atau tidak, hanya dengan fungsi baru yang mendatangkan profit sajalah, bangunan Cagar Budaya seperti itu akan bertahan.

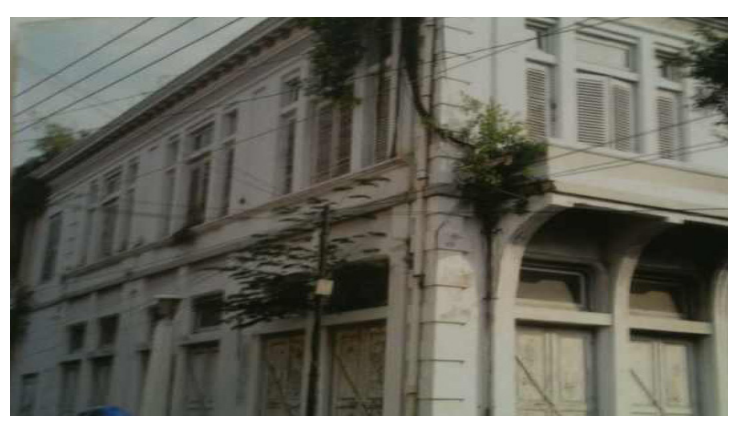

Gambar 1. Bangunan Semarang Contemporary Art Gallery sebelum direnovasi tahun 2007

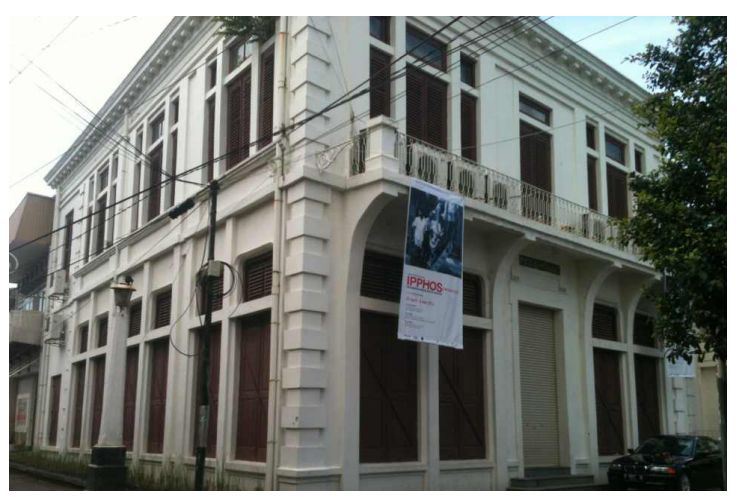

Gambar 2. Bangunan Semarang Contemporary Art Gallery setelah direnovasi

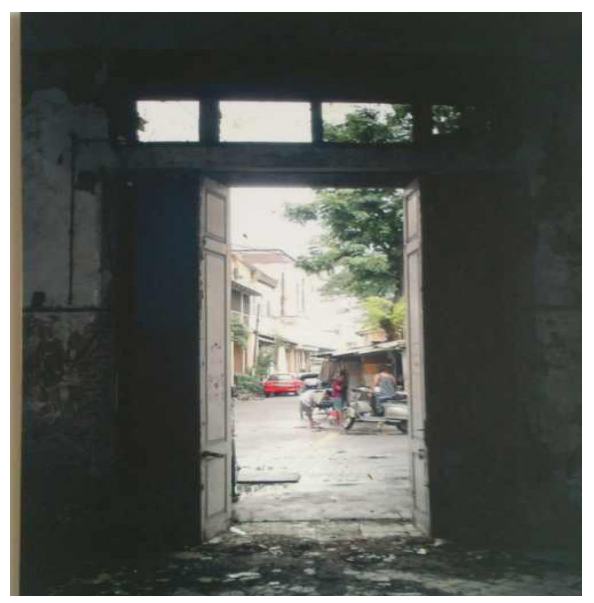

Gambar 3. Pintu dari dalam bangunan Semarang Contemporary Art Gallery sebelum direnovasi 


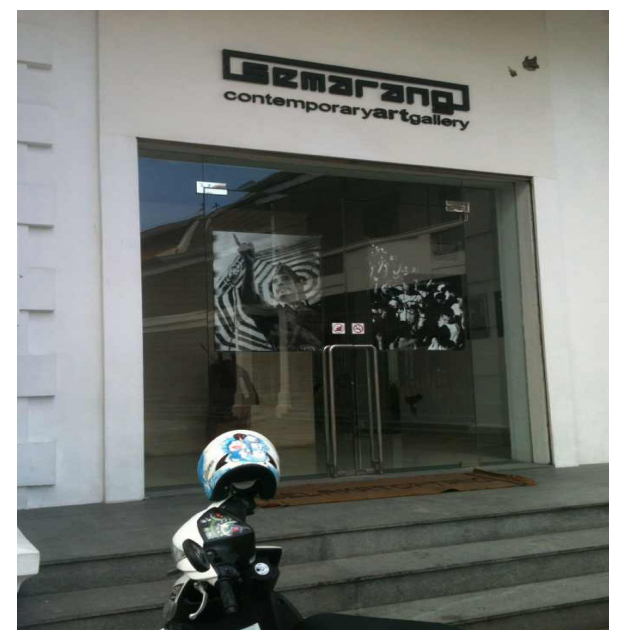

Gambar 4. Pintu dari luar bangunan Semarang Contemporary Art Gallery setelah direnovasi

Revitalisasi yang dilakukan oleh Pemerintah Kota Semarang sudah sesuai dengan UU No. 11 Tahun 2010 Tentang Cagar Budaya. Apabila melihat isi ketentuan Pasal $82 \mathrm{UU}$ No. 11 Tahun 2010 tentang Cagar Budaya dinyatakan bahwa revitalisasi Cagar Budaya harus memberi manfaat untuk meningkatkan kualitas hidup masyarakat dan mempertahankan ciri budaya lokal yaitu ciri asli dan/ atau muka Bangunan Cagar Budaya atau Struktur Cagar Budaya. Perubahan fungsi yang dilakukan oleh Pemerintah Kota Semarang erat kaitannya dengan perubahan struktur bangunan Cagar Budaya tersebut. Hal ini terlihat dari bangunan-bangunan yang telah berubah fungsi di Kota Lama Semarang. Sebagai Contohnya bangunan Semarang Contemporary Art Gallery yang merubah struktur pintu depan bangunan dengan kaca, serta perubahan dari lantai, dinding dan penambahan lampu di dalam ruangan tetapi tidak merubah struktur asli luar bangunan tersebut. Apabila dilihat dari kedua gambar, maka tidak ada perubahan struktur luar bangunan Cagar Budaya tersebut. Disini Pemerintah mempertahankan bentuk asli dari bangunan Cagar Budaya yang akan dialihkan fungsinya. Tetapi apabila melihat struktur dalam bangunan tersebut, telah terjadi perubahan struktur bangunan dari pintu, lantai, tangga serta penambahan lampu di dalam ruangan. Berikut ini adalah gambar pintu yang telah dirubah strukturnya.

Jika diperhatikan, bahwa perubahan fungsi dan struktur yang dilakukan oleh Pemerintah memberi manfaat dari segi fungsional-ekonomis yaitu memberi manfaat untuk meningkatkan kualitas hidup masyarakat. Revitalisasi yang digunakan Pemerintah Kota Semarang sebagai suatu tindakan pengembangan yang ditujukan untuk menumbuhkan kembali nilai-nilai penting Cagar Budaya dengan penyesuaian fungsi baru yang tidak bertentangan dengan prinsip pelestarian dan nilai budaya masyarakat sudah dilakukan oleh Pemerintah Kota Semarang berdasarkan UU No. 11 Tahun 2010 Tentang Cagar Budaya yaitu tercantum dalam Pasal 78 UU No. 11 Tahun 2010 Tentang Cagar Budaya dinyatakan bahwa pengembangan Cagar Budaya dilakukan dengan memperhatikan prinsip kemanfaatan, keamanan, keterawatan, keaslian, dan nilai-nilai yang melekat padanya. Tetapi keterawatan yang dimaksud dalam pasal tersebut tidak jelas antara keterawatan bangunan Cagar Budaya atau keterawatan lingkungan di sekitar bangunan tersebut. Hal itu sesuai dengan ketentuan Pasal 78 yang menyebutkan bahwa Pengembangan Cagar Budaya dilakukan dengan memperhatikan prinsip kemanfaatan, keamanan, keterawatan, keaslian, dan nilai-nilai yang melekat padanya. Setiap orang dapat melakukan Pengembangan Cagar Budaya setelah memperoleh: izin Pemerintah atau Pemerintah Daerah; dan izin pemilik dan/atau yang menguasai Cagar Budaya.

Pengembangan Cagar Budaya tersebut dapat diarahkan untuk memacu pengembangan ekonomi yang hasilnya digunakan untuk Pemeliharaan Cagar Budaya dan peningkatan kesejahteraan masyarakat. Setiap kegiatan pengembangan Cagar Budaya harus disertai dengan pendokumentasian. Apabila diperhatikan ketentuan isi Pasal 78 ayat (3) UU No. 11 Tahun 2010 Tentang Cagar Budaya tersebut bahwa kegiatan pengembangan Cagar Budaya hanya memperhatikan fungsional-ekonomisnya saja. Padahal faktor ekologis juga mempengaruhi kondisi suatu bangunan. Tetapi alangkah sebaiknya perubahan fungsi dan struktur yang dilakukan juga memperhatikan dari segi historis-filoso- 
fisnya dengan memperhatikan bentuk struktur asli dari bangunan Cagar Budaya tersebut. Hal tersebut menimbulkan dilema moral dan konservasi yang dilakukan oleh Pemerintah Kota Semarang terhadap perubahan fungsi dan struktur bangunan Cagar Budaya. Sehingga hal ini perlu diatur lebih khusus lagi ke dalam peraturan agar kegiatan-kegiatan pelestarian yang dilakukan dapat berjalan seimbang dengan mempertahankan nilai historisfilosofis, fungsional-ekonomis serta ekologis suatu bangunan Cagar Budaya. Tidak hanya membentuk peraturan saja tapi harus dilaksanakan atau diterapkan sesuai peraturan yang ada dan melakukan pengawasan secara terstuktur, intensif dan konsisten.

Tetapi sampai saat ini, penanganan dari Pemerintah Kota Semarang masih lambat. Hal tersebut juga terlihat dari perlindungan hukumnya, dimana sampai saat ini peraturan daerah kota Semarang yang terkait dengan Cagar Budaya belum dibentuk. Sehingga Pemerintah Kota Semarang masih memakai Peraturan Daerah Provinsi Jawa Tengah No. 10 Tahun 2013 tentang Pelestarian dan Pengelolaan Cagar Budaya Provinsi Jawa Tengah.

Menurut teori Lawrence Meir Friedman (2001:8) tentang sistem hukum bahwa Pemerintah Kota Semarang masih kurang dalam penegakan hukumnya apabila dilihat dari substansi hukum, struktur hukum dan budaya hukum. Dari substansi, dengan belum terbentuknya Peraturan Daerah Kota Semarang mengenai Cagar Budaya. Dari segi struktur, terlihat dari pengawasan terhadap bangunan Cagar Budaya yang kurang dikarenakan tenaga Dinas Tata Kota dan Perumahan Semarang terbatas. Dan dari segi budaya hukum, hal ini terlihat dari kurangnya kesadaran masyarakat dalam merawat bangunan Cagar Budaya dikarenakan hukum yang mengaturnya kurang tegas sehingga dapat mengakibatkan kurang berfungsinya hukum di masyarakat yang mempengaruhi tingkat kepatuhan masyarakat terhadap hukum. Lemahnya implementasi hukum Cagar Budaya di masyarakat mengakibatkan tidak tercapainya tujuan dari hukum itu sendiri dibentuk.

Menurut Hosiana L Tobing, dkk dalam penelitiannya pada tahun 2008 yang berjudul Studi Implementasi kebijakan Pe- merintah Kota Semarang dalam Upaya Melestarikan Bangunan Cagar Budaya di Kota Semarang bahwa kendala implementasi kebijakan Pemerintah Kota Semarang berupa aturan sudah diformulasikan dalam bentuk SK Walikota Semarang Nomor 646/50/1992 tentang Konservasi Bangunan-bangunan Kuno dan Bersejarah di Kota Semarang dan sudah diimplementasikan. Namun dalam pelaksanaannya terdapat berbagai kendala antara lain karena faktor komunikasi, lingkungan kebijakan, komitmen dan kondisi sosial, ekonomi dan politik.

Komunikasi pada dasarnya mempunyai fungsi yang cukup signifikan sebagai sarana untuk menyebarkan berbagai program pembangunan. Di sisi lain juga komunikasi dapat dijadikan sebagai alat kontrol yang cukup efektif dimana diharapkan akan menimbulkan persamaan persepsi, pengetahuan, pengertian serta partisipasi masyarakat. Selama ini sebelum dibentuknya Tim Ahli Cagar Budaya, jajaran di Pemerintah Kota Semarang masih kurang melakukan komunikasi dengan para pemilik bangunan dan pemakai bangunan Cagar Budaya di Kota Semarang. Minimnya informasi dan arahan menimbulkan kebingunan tentang bagaimana memperlakukan bangunan Cagar Budaya, seperti untuk merawat, memelihara, dan merenovasi. Sesuai dengan pernyataan informan dari akademisi bahwa seharusnya Pemerintah Kota Semarang membuat aturan yang tegas kemudian disosialisasikan, agar diketahui oleh masyarakat. Pemerintah tidak hanya melarang atau mengatur, tapi juga dapat memberi jalan keluar yang baik.

Lingkungan kebijakan juga berpengaruh dalam implementasi, terutama aktor yang terlibat karena kekuasaan dan adanya kepentingan. Kepala Daerah dan seluruh jajarannya sebagai pihak yang sangat menentukan keberhasilan suatu implementasi. Seringkali antara kebijakan dengan pelaksanaannya tidak sejalan. Akibatnya timbul berbagai kendala seperti pelanggaran dari ketentuan. Sebagai contoh kasus Pasar Johar yang sampai saat ini masih dipermasalahan, antara pelestarian dan kepentingan komersial. Pro dan kontra pun tidak dapat dielakkan akibat pernyataan Walikota yang banyak me- 
nuai kecaman. Setiap pelanggaran tentu ada perlakuan yang diperoleh sebagai akibatnya, berupa sanksi. Namun saat ini belum pernah ada sanksi yang tegas. Selama ini tidak ada kejelasan sanksi terhadap pelanggaran yang menyangkut bangunan Cagar Budaya, walaupun ada kebijakan namun belum ada aturan yang menjurus pada penegakan hukum (law inforcement).

Kendala yang terakhir menyangkut adanya pengaruh sosial ekonomi dan politik dalam upaya untuk melestarikan bangunan cagar Budaya di Kota Semarang. Pengaruh yang paling kuat berhubungan dengan ekonomi. Keinginan untuk membongkar berbagai bangunan Cagar Budaya kerap terjadi, khususnya dari para pebisnis dan pengembang (investor). Mereka umumnya ingin membangun mall, supermall atau pusat-pusat perbelanjaan modern yang mempunyai nilai ekonomi yang tinggi. Akibatnya sering terjadi suatu dilema antara kepentingan ekonomi dengan pelestarian bangunan cagar Budaya. Peran Pemerintah Kota Semarang harus kuat. Kebijakan yang ada harus jelas dioperasionalkan. Kenapa harus membongkar bangunan cagar Budaya yang ada, sementara kalau ingin membangunan pusat perbelanjaan modern dapat juga memanfaatkan lahan yang masih cukup luas di Kota Semarang.

Berdasarkan penelitian yang dilakukan oleh Hosiana L. Tobing, dkk (2008), bahwa faktor utama kendala implementasi kebijakan di masyarakat menurut peneliti adalah lingkungan kebijakan. Sesuai dengan pernyataan dari Pihak Dinas tata Kota dan Perumahan Semarang bahwa kebijakan hanya berupa wacana. Secara operasional kebijakannya lemah, prosedur tekhnis belum ada, SDM masih minim dan anggarannya terbatas, sanksinya kurang tegas. Di dalam SK Walikota secara implisit tidak tertera, sehingga pelanggaran yang terjadi dikenakan sanksi yang ada pada Peraturan Daerah Provinsi Jawa Tengah No. 10 Tahun 2013 tentang Pelestarian dan Pengelolaan Cagar Budaya Provinsi Jawa Tengah. Tetapi belum ada kejelasan sanksi terhadap pelanggaran yang menyangkut bangunan Cagar Budaya.

Apabila aturan tersebut mempunyai sanksi yang tegas maka segala pelanggaran atau tindakan yang merobohkan bangunan Cagar Budaya tidak akan terjadi yang dilakukan Pemerintah terhadap Gedung Griss yang sekarang diubah menjadi Mall Paragon. Gedung tersebut dijual kepada Pihak Swasta untuk dijadikan Mall. Hal ini sudah melanggar Pasal 16 ayat (4) UU No. 11 tahun 2010 tentang Cagar Budaya yang berbunyi : "Cagar Budaya yang telah dimiliki oleh Negara tidak dapat dialihkan kepemilikannya". Tetapi hal tersebut, dibantah oleh Pihak Dinas Tata Kota dan Perumahan Semarang dan Pihak dari BAPPEDA Kota Semarang. Bangunan

Tabel 1. Daftar Bangunan Cagar Budaya yang hilang

\begin{tabular}{|c|c|c|c|}
\hline & Nama bangunan & Lokasi & Keterangan \\
\hline 1. & Eks Kantor DPU Semarang & Jl Pemuda & Dirobohkan, diganti baru \\
\hline 2. & Kantor Polwil & إl Pemuda & Diganti bangunan baru \\
\hline 3. & Kantor Kodam & JI S Parman & Dirobohkan \\
\hline 4. & BCA Jl Suari & Jl Suari & Diganti bangunan baru \\
\hline 5. & Bank Perniagaan Indonesia & I Pemuda & Dibongkar \\
\hline 6. & Kantor PLN & إj Pemuda 94 & Roboh \\
\hline 7. & House of Dr Gan Sing Bie & Jl Gajahmada & Dibongkar tahun 1995 \\
\hline 8. & Gedung gula & Jl Sebandaran & Dibongkar \\
\hline 9. & Asrama Kowal & Jl Sultan Agung & Dibongkar \\
\hline 10. & Rumah & Jl Gajahmada 78 & Dibongkar \\
\hline 11. & Gedung PT Permorin & Jl Pemuda 96 & Dibongkar tahun 1997 \\
\hline 12. & Hotel Jansen & Jl Letjen Suprapto & Dibongkar \\
\hline 13. & Gedung Gris & I Pemuda & Dibongkar \\
\hline 14. & Surau Kampung Kulitan & Jl MT Haryono & Dibongkar \\
\hline 15. & Rumah tinggal & Jl S Parman 78 & Dibongkar tahun 1995 \\
\hline 16. & Balai Yasa PT Kereta Api & Jl Pengapon & Rusak, dibongkar \\
\hline 17. & Bioskop Murni & Jl Gajahmada & Dibongkar, diganti baru \\
\hline 18. & Bioskop Gelora & I MT Haryono & Dibongkar, diganti baru \\
\hline
\end{tabular}

Sumber : Suara Merdeka, Edisi 20/1/2005 
Griss tersebut masuk ke dalam daftar bangunan Cagar Budaya yang hilang (Suara Merdeka, Edisi 20/1/2005). Daftar bangunan Cagar Budaya yang dinyatakan hilang sebagaimana terlihat pada Tabel 1.

Selain itu, di dalam SK Walikota tersebut hanya tercatat 111 bangunan kuno yang dilindungi, padahal sampai saat ini tercatat ada 315 bangunan kuno yang dilindungi berdasarkan dokumen dari BAPPEDA dan Dinas Tata Kota dan Perumahan Semarang. Hal tersebut sudah menjadi tidak relevan lagi untuk melindungi bangunan-bangunan kuno yang ada di Kota Semarang. Sehingga pelestariannya sendiri menggunakan Peraturan Daerah Provinsi Jawa Tengah No. 10 Tahun 2013 tentang Pelestarian dan Pengelolaan Cagar Budaya Provinsi Jawa Tengah.

Akibat dari faktor tersebut, masyarakat menjadi kurang dalam menaati aturan yang sudah ada dikarenakan sanksi yang dikenakan kurang tegas. Sehingga banyak bangunan yang kosong dan kurang dirawat oleh pemiliknya maupun pengguna bangunan tersebut. Hal tersebut menjadi alasan Pemerintah merubah fungsi bangunan Cagar Budaya dan strukturnya dengan tidak merubah bentuk aslinya agar bangunan tersebut dapat difungsikan dengan baik dan dirawat. Namun revitalisasi yang dilakukan oleh Pemerintah sampai saat ini hanya pelestarian bangunan saja. Padahal faktor lingkungan juga berpengaruh terhadap kerusakan bangunan. Hal ini tidak sejalan dengan Pasal 2 Peraturan Daerah Kota Semarang No. 5 Tahun 2009 tentang Bangunan Gedung yang dinyatakan bahwa maksud pengaturan gedung adalah pengendalian pembangunan yang berlandaskan asas kemanfaatan, keselamatan, kenyamanan, keseimbangan, serta keserasian bangunan gedung dengan lingkungannya. Sampai saat ini belum ada ketentuan khusus mengenai sanksi terhadap Pemerintah yang melakukan pelanggaran terhadap ketentuanketentuan yang ada. Menurut penulis, sebaiknya perlu diadakan sanksi administratif secara bertahap kepada Pemerintah yang melakukan pelanggaran yaitu didahului dengan sanksi administratif yang ringan hingga sanksi yang terberat.

Apabila melihat Tenaga Pemerintah yang terbatas saat ini, perlu adanya dukungan dari masyarakat untuk membantu, berinisiatif serta berkontribusi dalam pelestarian bangunan Cagar Budaya demi kesejahteraan bersama. Tetapi faktanya budaya bersih, merawat, kesadaran dalam masyarakat belum tumbuh sehingga perlu disosialisasikan dengan baik oleh Pemerintah dan saling kerjasama dalam aspek budaya menjaga lingkungan dengan memberikan reward dan funishment kepada masyarakat. Warisan budaya yang berupa peninggalan fisik-visual yang sangat berharga itu patut untuk segera mendapat penanganan dan pemeliharaan yang serius agar tidak terkikis dan rusak oleh laju perkembangan waktu, dengan segala dampak modernitas yang tidak terkontrol dan cenderung merusak lingkungan serta meninggalkan tradisi.

Tuntutan kebutuhan yang semakin kompleks dan semakin sempit lahan untuk pembangunan serta kurangnya kesadaran masyarakat untuk menghargai dan memelihara bangunan-bangunan kuno akibat terawatnya bangunan tersebut, mengakibatkan karya arsitektur yang sebenarnya bernilai sejarah, berpenampilan indah dan unik itu tersembunyi, terdesak dan bahkan tergusur sehingga keindahan tersebut tidak lagi dapat dinikmati oleh masyarakat luas.

Pemanfaatan bangunan kuno dengan menambah fungsi baru sesuai dengan tuntutan kebutuhan sekarang, tanpa merubah dan merusak bentuk yang sudah ada, akan menciptakan kesan tersendiri sekaligus menyimpan dan memelihara catatan sejarah yang berupa peninggalan fisik-visual tersebut. Dengan demikian jati diri sebuah kota dapat terlihat di samping dapat terbaca sejarah masa lalu yang telah ikut menciptakan keanekaragaman masa kini, sehingga harapan kota Semarang sebagai kota yang berwawasan budaya dapat terwujud.

\section{b. Proses Perizinan bangunan Sema- rang Contemporary Art Gallery yang sudah dialihkan fungsinya}

Dalam menjalankan fungsinya hukum memerlukan berbagai perangkat dengan tujuan agar hukum memiliki kinerja yang baik. Salah satu kinerja yang membedakan 
dengan yang lain adalah bahwa hukum memiliki kaidah yang bersifat memaksa, artinya apabila kaidah hukum dituangkan ke dalam suatu perundang-undangan maka setiap orang harus melaksanakannya. Izin merupakan perangkat hukum administrasi yang digunakan pemerintah untuk mengendalikan warganya agar berjalan dengan teratur dan untuk tujuan ini diperlukan perangkat administrasi. Salah satu perangkat admnistrasi adalah organisasi, dan agar organisasi ini berjalan dengan baik, perlu dilakukan pembagian tugas. Sendi utama dalam pembagian tugas adalah adanya koordinasi dan pengawasan. (Ridwan, 2009 : 90). Hal ini sejalan dengan diberlakukannya UU No. 12 tahun 2008 tentang Perubahan Kedua atas UU No. 32 Tahun 2004 tentang Pemerintah Daerah, dimana daerah diberi kebebasan untuk menyelenggarakan urusan rumah tangganya sendiri. Dengan adanya kondisi tersebut, maka pemerintah daerah memberlakukan suatu ketentuan tentang perizinan yang diadakan untuk mewujudkan tertib administrasi dalam melaksanakan pembangunan di daerah. Begitu pula halnya dengan perizinan suatu bangunan termasuk bangunan Cagar Budaya.

Proses perizinan yang dilakukan oleh Pemilik Gedung Semarang Contemporary Art Gallery kepada pemerintah merupakan suatu perwujudan dari berfungsinya suatu hukum. Dalam hal ini, izin bersifat konkret. Artinya obyek yang diputuskan dalam tata usaha negara itu tidak abstrak melainkan berwujud, tertentu, dan ditentukan. Izin memiliki sifat individual, artinya bahwa dalam izin itu harus disebutkan dengan jelas siapa yang diberikan izin. Izin bersifat final, dimana dengan izin seseorang telah mempunyai hak untuk melakukan suatu perbuatan hukum sesuai dengan isinya yang secara definitif dapat menimbulkan akibat hukum tertentu. Sehingga dengan perizinan ada sesuatu yang dituju yaitu :

a. Keinginan mengarahkan aktivitas tertentu.

b. Mencegah bahaya yang mungkin akan timbul, sebagai contoh dalam izin yang berkaitan dengan lingkungan, yaitu izin dapat mencegah adanya pembuangan limbah yang ber- lebihan.

c. Untuk melindungi obyek-obyek tertentu, seperti cagar budaya dan lain sebagainya.

d. Membagi benda-benda yang sedikit.

e. Mengarahkan orang-orang tertentu yang dapat melakukan aktivitas.

Berdasarkan bagan tersebut dapat dilihat bahwa salah satu tujuan dibuatnya perizinan adalah untuk melindungi cagar budaya. Dalam hal ini bangunan Semarang Contemporary Art Gallery merupakan bangunan Cagar Budaya yang tercatat dalam data bangunan Cagar Budaya oleh Dinbudpar dan Kepwal serta dalam Senarai Inventarisasi dan Dokumentasi Bangunan dan Kawasan Pusaka Budaya Kota Semarang yang diperoleh Penulis dari proses wawancara kepada Pihak Dinas Tata Kota dan Perumahan Semarang. Dalam deklarasi ASEAN tentang Pusaka Budaya Tahun 2000 menyatakan bahwa yang dimaksud dengan pusaka budaya dalam deklarasi ASEAN tentang Pusaka Budaya adalah :

a. Nilai-nilai dan konsep-konsep budaya yang penting;

b. Struktur dan artifak : tempat tinggal, bangunan pemujaan, struktur-struktur utilitas, karya-karya seni rupa, alat-alat dan peralatan yang bersejarah, estetis, ataupun ilmiah;

c. Site dan habitat manusia ; ciptaan manusia ataupun kombinasi ciptaan manusia dan alam, situs-situs arkeologi dan situs tempat tinggal masyarakat manusia yang bernilai luar biasa dari sudut pandang historis, estetis, antropologis maupun ekologis, atau karena segi-segi alamiahnya, atau kepentingannya sebagai habitat bagi keberlangsungan budaya dan identitas dari tradisi hidup tertentu;

d. Pusaka lisan atau pusaka rakyat : adat istiadat, dongeng/cerita rakyat, bahasa dan sastra, kesenian tradisional dan kerajinan rakyat, seni pertunjukan, permainan, sistem pengetahuan pribumi serta praktek-praktek, mitos, adat dan kepercayaan, ritual, dan tradisi hidup lainnya;

e. Pusaka tertulis; 


\section{Sebelum Difungsikan}

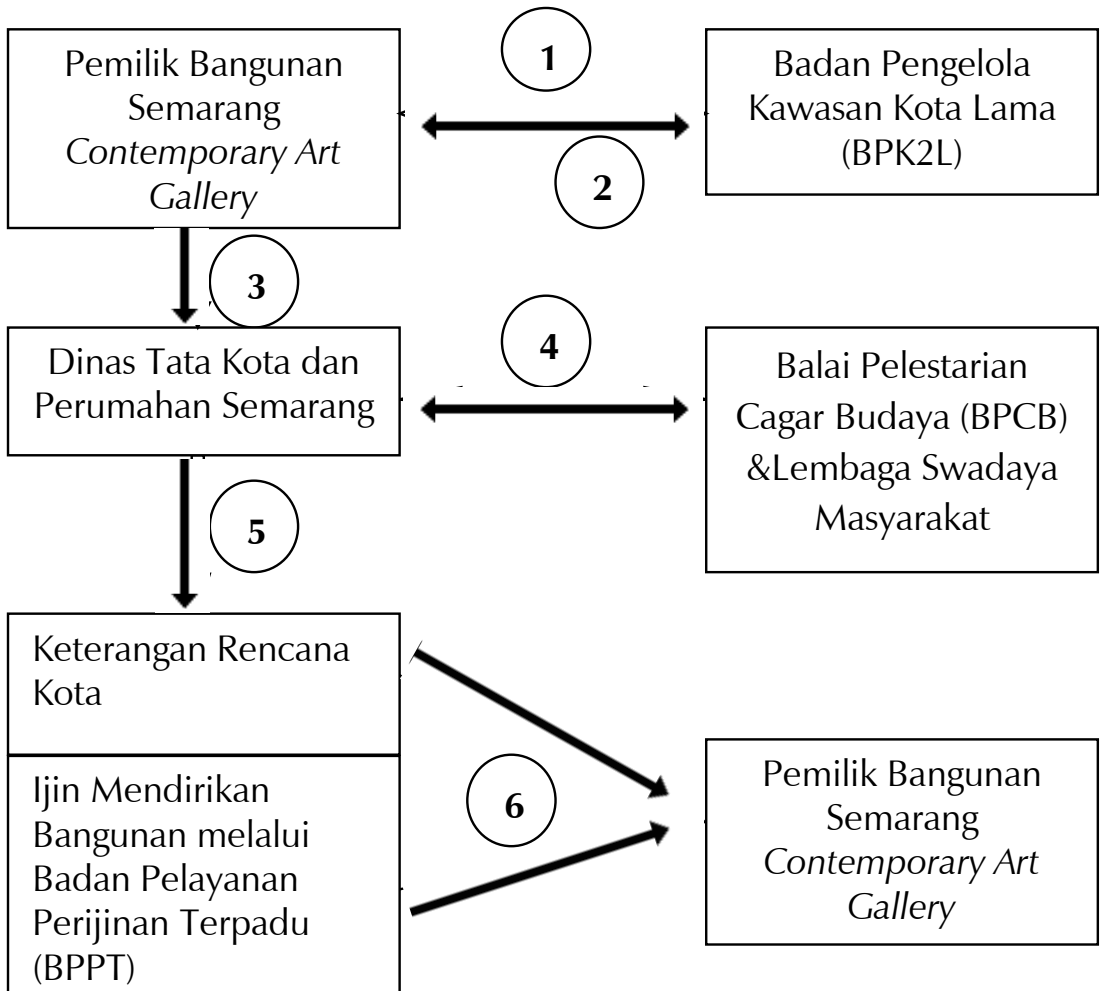

Gambar 1. Skema Proses Perijinan Bangunan Cagar Budaya oleh Dinas Tata Kota dan Perumahan Semarang

Keterangan :

1. Sebelum difungsikan, Pemilik bangunan Semarang Contemporary Art Gallery ke Badan Pengelola Kawasan Kota Lama (BPK2L)

2. mendapat kajian tentang bangunan tersebut dari Badan pengelola Kawasan Kota Lama (BPK2L)

3. Setelah mendapat rekomendasi dari Badan Pengelola Kawasan Kawasan Kota Lama (BPK2L) tersebut, Pemilik bangunan Semarang Ccontemporary Art Gallery ke Dinas Tata Kota dan Perumahan Semarang untuk mendapatkan keterangan rencana kota dan Ijin Mendirikan Bangunan.

4. Dinas Tata Kota dan Perumahan Semarang berunding atau merapatkan dengan Balai Pelestarian Cagar Budaya (BPCB) dan Lembaga Swadaya Masyarakat terkait dengan rekomendasi dari Badan Pengelola Kawasan Kota Lama (BPK2L). Setelah adanya Tim Ahli Cagar Budaya, maka akan dirapatkan lebih mendalam lagi dengan Tim Ahli Cagar Budaya dan BPCB.

5. Setelah berunding, dan mendapat persetujuan dari BPCB dan LSM, maka Dinas Tata Kota dan Perumahan Semarang mengeluarkan Keterangan Rencana Kota dan Ijin Mendirikan Bangunan (IMB) melalui Badan Pelayanan Perijinan Terpadu (BPPT).

6. Keterangan Rencana Kota dan IMB tersebut, diberikan kepada Pemilik Bangunan Contemporary Art Gallery.

7. Setelah akan difungsikan, Dinas Tata Kota dan Perumahan Semarang akan mengeluarkan Ijin Gangguan (H.O) dan Surat ljin Usaha Perdagangan (SIUP) melalui BPPT.

8. Ijin Gangguan dan SIUP tersebut diserahkan kepada Pemilik Bangunan Semarang Contemporary Art Gallery. 
f. Pusaka budaya populer : kreativitas popular dalam budaya masa (misalnya budaya industri atau komersial), bentuk-bentuk ekspresi popular dengan bentuk estetika yang luar biasa, nilai-nilai antropologis dan sosiologis, termasuk musik, tari, seni grafis, fashion, permainan dan olahraga, desain industri, sinema, televisi, video musik, seni video dan seni cyber dalam masyarakat urban yang berorientasi teknologi.

Hal tersebut telah tercantum dalam deklarasi ASEAN tentang pusaka budaya (ASEAN declaration on cultural heritage 2000). Di dalam deklarasi tersebut menyatakan bahwa merupakan tugas utama dari setiap negara Anggota ASEAN untuk mengindentifikasi, menggambarkan, melindungi, melestarikan, memajukan, mengembangkan, dan meneruskan ke generasi berikutnya pusaka budaya yang penting dalam wilayahnya dan memanfaatkan bantuan dan kerjasama regional dan internasional, ketika diperlukan dan tepat. Meskipun benar-benar menghormati kedaulatan dan hak kekayaan nasional setiap Negara Anggota, ASEAN mengakui bahwa pusaka budaya nasional dari Negara-negara Anggota merupakan pusaka Asia Tenggara dimana ASEAN sebagai suatu kesatuan yang memiliki kewajiban untuk bekerjasama dalam melindunginya. Hal ini menuntut setiap Negara Anggota ASEAN untuk merumuskan dan memakai kebijakan-kebijakan, programprogram, dan layanan dan mengembangkan tindakan-tindakan tekhnis, ilmiah, hukum, administratif dan keuangan yang tetap dalam perlindungan benda pusaka tersebut.

Terkait dengan hal itu, maka izin merupakan suatu perangkat hukum administasi yang digunakan pemerintah untuk mengendalikan warganya yang menimbulkan akibat hukum. Adanya kegiatan perizinan yang dilaksanakan oleh pemerintah pada intinya adalah untuk menciptakan kondisi bahwa kegiatan pembangunan sesuai peruntukkan, disamping itu agar lebih berdaya guna dan berhasil guna dalam rangka pelayanan terhadap masyarakat dan pembangunan. Lebih jauh lagi melalui sistem perizinan diharapkan dapat tercapainya tujuan tertentu di antaranya :

a. adanya suatu kepastian hukum.

b. perlindungan kepentingan umum.

c. pencegahan kerusakan atau pencemaran lingkungan.

d. pemerataan distribusi barang tertentu.

Tetapi faktanya, apabila melihat langsung kondisi lingkungan kawasan kota Lama Semarang, Pemerintah hanya membangun, merenovasi suatu bangunan Cagar Budaya tanpa melihat lingkungan di sekitarnya. Sehingga sampai saat ini masih terjadi banjir, rob di kawasan tersebut. Disini perlu adanya peran masyarakat untuk membantu perawatan kawasan. Tapi tanpa adanya sosialisasi dan sanksi yang tegas dari pemerintah, maka hal tersebut hanyalah harapan atau anganangan belaka. Dalam hal ini selain pemerintah melakukan tindakan hukum administrasi yaitu mengeluarkan izin, pemerintah juga melakukan tindakan nyata atau yang disebut dengan Perbuatan Materiil (Feitelijke Handelingen) sebagaimana dinyatakan oleh Van Vollenhoven bahwa suatu pekerjaan pemerintahan untuk sebagian besar ditujukan kepada usaha memenuhi kebutuhan nyata, untuk sebagian bergerak di luar bidang hukum seperti pemasangan lampu jalan, penataan taman, membangun infrastruktur jalan dan lain-lain. Dengan kata lain, tindakan nyata itu merupakan tindakan yang tidak ada relevansinya dengan hukum dan oleh karenanya tidak menimbulkan akibat hukum (Ridwan, 2009 : 141).

Tindakan nyata yang dilakukan oleh Pemerintah kota Semarang sampai saat ini adalah dengan membantu dan memperbaiki infrastuktur jalan dan saluran dan mengawasi perbaikan bangunan Cagar Budaya yang akan diubah fungsinya. Dimana butuh management dan maintenance tindakan dari Pemerintah yang konsisten dan terstruktur serta partisipasi dari masyarakat untuk merawat infrastuktur yang sudah ada agar kawasan kota Lama Semarang menjadi kawasan 
wisata yang terawat, bersih, selain menjadi income bagi daerah juga menjadi salah satu icon pariwisata di kota Semarang.

\section{Simpulan}

Berdasarkan hasil penelitian, analisis, dan pembahasan oleh peneliti, maka dapat disarikan beberapa kesimpulan sebagai berikut. Pertama, tindakan Pemerintah melakukan perubahan fungsi maupun sktruktur bangunan Cagar Budaya adalah untuk merevitalisasi bangunan tersebut yaitu suatu kegiatan pengembangan yang ditujukan untuk menumbuhkan kembali nilai-nilai penting Cagar Budaya dengan penyesuaian fungsi ruang baru yang tidak bertentangan dengan prinsip pelestarian dan nilai budaya masyarakat sesuai dengan Pasal 80 Undang-Undang No. 11 Tahun 2010 Tentang Cagar Budaya. Sebagai salah satu tindakan pelestarian yang dilakukan oleh Pemerintah Kota Semarang terhadap bangunan Cagar Budaya kota Semarang dengan menghidupkan kembali kawasan kota Lama Semarang yang mempunyai nilai falsafah dari segi pendidikan, sejarah maupun nilai-nilai penting yang terkandung di dalamnya.

Kedua, proses perizinan Bangunan Semarang Contemporary Art Gallery kepada Pemerintah Kota Semarang melalui beberapa tahapan di Badan Pengelola Kawasan Kota Lama bersama Balai Pelestarian Cagar Budaya (BPCB) dan Lembaga Swadaya Masyarakat terkait dengan rekomendasi dari Badan Pengelola Kawasan Kota Lama (BPK2L). Setelah adanya Tim Ahli Cagar Budaya, maka akan dirapatkan lebih mendalam lagi dengan Tim Ahli Cagar Budaya dan BPCB. Setelah akan difungsikan, Dinas Tata Kota dan Perumahan Semarang akan mengeluarkan ljin Gangguan (H.O) dan Surat Ijin Usaha Perdagangan (SIUP) melalui BPPT.

\section{Daftar Pustaka}

Bappeda Kota Semarang. 2006. Senarai : Inventarisasi dan Dokumentasi Bangunan dan Kawasan Pusaka Budaya Kota Semarang. Semarang : Bappeda Pemerintah Kota Semarang.

HR, Ridwan. 2011. Hukum Administrasi Negara. Jakarta : PT. Raja Grafindo Persada.

Kaloh, DR. J. 2007. Mencari Bentuk Otonomi Daerah: Suatu Solusi dalam Menjawab Kebutuhan Lokal dan Tantangan Global. Jakarta : PT. Rineka Cipta.

Kompas, Bangunan Tua di Kota Lama Semarang Roboh. (2013). http://regional.kompas.com/ $\mathrm{read} / 2013 / 01 / 13 / 1613465 /$ Bangunan. Tua. di.Kota.Lama.Semarang. Roboh....., Edisi 13/1/2013 (diakses 04/01/2013)

Ridwan, Juniarso dan Sudrajat, Achmad Sodik. 2009. Hukum Administrasi Negara dan Kebijakan Pelayanan Publik. Bandung : Nuansa.

Soemitro, Ronny Hanitijo. 1990. Metodologi Penelitian Hukum dan Jurimetri. Jakarta : Ghalia Indonesia.

Tobing, Hosiana L, dkk. 2008. Studi Implementasi kebijakan Pemerintah Kota Semarang dalam Upaya Melestarikan Bangunan Cagar Budaya di Kota Semarang. Artikel diunduh di eprints.undip. ac.id/.../Artikel_Hosiana_L.Tobing.pdf (diakses 21/3/14)

Waridah, Siti., dkk. 2000. Antropologi. Jakarta :PT. Bumi Aksara.

\section{Peraturan Perundang-Undangan}

Undang-Undang Nomor 11 tahun 2010 tentang Cagar Budaya

Peraturan Daerah Kota Semarang Nomor 5 Tahun 2009 tentang Bangunan Gedung.

Peraturan Daerah Provinsi Jawa Tengah Nomor 10 Tahun 2013 tentang Pelestarian dan Pengelolaan Cagar Budaya Provinsi Jawa Tengah. 